\title{
Design of Information System Monitoring Complaints Targeting COVID-19 Vaccination For The General Public Based On The Web (Case Study of Bandung Health Office)
}

\author{
Reihan Fazri Aldiansyah ${ }^{1}$, Syams Syair Ramadhan ${ }^{2}$, Jaenal Arifin ${ }^{3}$, Cahyadi Agustin ${ }^{4}$ \\ ${ }^{1,2,3,4}$ Polytechnic Piksi Ganesha; Jend. Gatot Subroto Street No.301, Bandung, 40274, Indonesia, \\ Tel. (022) 87340030/Fax. (022) 87340086 \\ ${ }^{5}$ Information System Management, School of Computer Engineering, Bandung \\ e-mail:*11rfaldianysah@piksi.ac.id, ${ }^{2}$ ssramadhan@ piksi.ac.id, ${ }^{3}$ jaenal.arifin@piksi.ac.id, \\ ${ }^{4}$ cahyadi.agustin3@gmail.com
}

\begin{abstract}
Abstrak
Dinas Kesehatan Kota Bandung sebagai Instansi Kesehatan yang selalu memberikan mutu pelayanan saat ini terpusatkan pada penanganan pandemi, terutama dalam pelaksanaan program vaksinasi sebagai strategi penanggulangan wabah COVID-19. Maka diperlukan pemantauan terhadap keluhan yang dialami masyarakat pasca vaksinasi. Permasalahan yang dialami saat ini adalah belum tersedianya wadah untuk menampung dan mengelola data keluhan vaksinasi COVID-19 dengan menggunakan sistem informasi. Tujuan dari penelitian ini adalah untuk merancang sistem informasi berbasis website yang mendukung proses monitoring dan penanganan keluhan vaksinasi COVID-19 di Dinas Kesehatan Kota Bandung dengan menyajikan data yang informatif dan transparan sehingga memudahkan masyarakat dalam melaporkan dan memperoleh informasi keluhan. Metode pengembangan sistem menggunakan model waterfall, sedangkan metode perancangan fungsional sistem menggunakan pendekatan pemodelan berorientasi objek dengan Unified Modelling Language (UML). Hasil pengujian Black box memperoleh nilai persentase keberhasilan fungsionalitas sistem sebesar 100\%. Hasil pengujian evaluasi dengan kuisioner System Usability Scale (SUS) memperoleh hasil akhir nilai pengujian sebesar 77.6 dengan kategori Acceptable dan Grade Scale B. Maka berdasarkan hasil pengujian, sistem dapat berjalan dengan mudah sesuai kebutuhan pengguna. Penelitian ini menghasilkan sistem informasi berbasis web yang mempermudah petugas kesehatan dalam mengelola data pelaporan keluhan vaksinasi COVID-19 dengan efisien.
\end{abstract}

Kata kunci- Perancangan Sistem Informasi, Vaksinasi, COVID-19, Web, CodeIgniter.

\section{Abstract}

Bandung Health Office as a Health Agency that always provides quality services is currently focused on handling pandemics, especially in the implementation of vaccination programs as a strategy to combat the COVID-19 outbreak. Therefore, monitoring of complaints experienced by the community after vaccination is required. The problem experienced today is the unavailability of containers to accommodate and manage data on COVID-19 vaccination complaints using the information system. The purpose of this research is to design a websitebased information system that supports the process of monitoring and handling COVID-19 vaccination complaints in the Bandung Health Office by presenting informative and transparent data so as to facilitate the public in reporting and obtaining complaint information easily. The system development method uses waterfall model, while the system functional design method 
uses object-oriented modeling approach with Unified Modelling Language (UML). Black box test results obtained a $100 \%$ percentage of system functionality success. Evaluation test results with System Usability Scale (SUS) questionnaire obtained the final test score of 77.6 with Acceptable category and B Grade Scale. So based on the test results, the system can run easily according to the needs of the user. This research resulted in a web-based information system that makes it easier for health workers to efficiently manage COVID-19 vaccination complaint reporting data.

Keywords—Information System Design, Vaccination, COVID-19, Web, CodeIgniter.

\section{INTRODUCTION}

$C$ oronavirus Disease 2019 or (COVID-19) is an infectious disease outbreak that until now continues to grow and is still in the global spotlight. The pandemic that has hit Indonesia since March 2020 has had a noticeable impact on various aspects of life, especially the significant impact on public health aspects so that the implementation of services in the health sector is currently focused on handling COVID-19. One form of government handling strategy together with all local health agencies in breaking the chain of the spread of the COVID-19 outbreak is to implement the COVID-19 vaccination program. Vaccination is the right step to obtain the formation of a specific immune system to avoid transmission of the COVID-19 virus [1]. Based on official data on vaccine status from the Ministry of Health as of July 11, 2021, the total target of vaccination targets for the first and second doses is 40,349,049 people. With the total number of Indonesians who have received the first dose vaccination as many as 36,278,606 people $(89.91 \%)$ and the total who received the second dose vaccination as many as $15,016,402$ people $(37.22 \%)$ [2].

To achieve communal immunity (herd immunity) for the community, the government accelerated COVID-19 vaccination by targeting 1 million doses of vaccine per day, at least $70 \%$ of the total population of Indonesia must receive vaccination [3]. But based on the data of daily vaccination achievements, the expected amount is still very far from the total target, meaning the dissemination of information and education about the importance of the COVID-19 vaccination program has not been delivered to the most. Government socialization is not fully responded to by the public [4]. This is due to the circulation of incorrect information or hoaxes about the COVID-19 vaccine that spread on the internet or social media as well as public doubts about the safety and effectiveness of vaccines, especially related to public complaints about side effects after receiving the vaccine. In general, no vaccine is without risk. Reasonable complains after receiving the vaccine only cause mild side effects with symptoms such as soreness, nausea, chills, and swelling at the injection site [5]. This is a sign that the vaccine triggers the body to build antibodies to fight viruses that may be infecting. But in other cases vaccines can cause unwanted complaints, it can also be called the Post-Immunization Follow-up Event (KIPI) which is a sick event that occurs after immunization and is suspected to be related to vaccine side effects [6]. So that it is necessary to monitor the complaints experienced by the community after receiving vaccinations [7]. The implementation of COVID-19 vaccination is carried out gradually in all areas, especially in Bandung, West Java, of course by looking at the availability, time of arrival, and safety aspects of vaccines [8].

Bandung Health Office is an Agency responsible in the field of health as the vanguard with one of its main tasks is to provide coaching services to improve the level of public health in the city of Bandung to improve the quality of health services. Bandung Health Office together with all local Technical Implementation Units is health workers who play an important role in

Reihan, et., al [Design of Information System Monitoring Complaints Targeting COVID-19 Vaccination For The General Public Based On The Web (Case Study of Bandung Health Office)] 
implementing the COVID-19 vaccination program. Intensively monitoring the people who have been vaccinated for early treatment by health officials, if complaints are found against the side effects experienced from vaccines. Monitoring is important to know the anticipation and handling of vaccine safety risks to prevent the decrease in acceptance of the COVID-19 vaccine in the community. But currently, there is no information system used as a forum to accommodate and manage COVID-19 vaccination complaint data for the community. The mechanism of handling complaints is still less effective and is also done conventionally in terms of the shelter of incoming complaints, management of complaint data, follow-up of complaints, as well as the recording of complaint report data. Namely, the community reported his complaint by calling the phone number of health officials provided by Bandung City Health Office as well as local health care facilities that carry out vaccinations. The way of reporting is less effective because, it can be at risk of the health worker's phone number is lost or difficult to contact so that the slow response and follow-up handling of complaints from health care facilities local health care officials, will result in data on community vaccination complaints are not recorded and not monitored properly.

To self-report complaints experienced after receiving COVID-19 vaccination have been provided through the official website of the Ministry of Health. However, on the official website, some shortcomings are difficult for the public to monitor complaints that have been reported because of the lack of features to track complaint reporting. Then the public cannot see the status of the progress of complaints that have been reported, whether the complaint has been followed up or is still in process. The reporting system on the official website is done in one direction to the community so that the public can only report complaints without being able to see the complaint information that has been followed up. The lack of information presented by the official website about the data of COVID-19 vaccination complaints makes the public uninterested and ignores the official website, so prefer to report complaints directly through the phone number provided by health workers from the health care facility, where the vaccination is carried out.

With the development of information technology, the use makes it possible to create more informative and systematized containers. Based on the background and description of the problem, the writers propose the title "Design of Information System Monitoring Complaints Targeting COVID-19 Vaccination for the General Public Based on the Web". The purpose of this research is to design a website-based information system that supports the process of monitoring and handling COVID-19 vaccination complaints at Bandung Health Office by presenting informative and transparent data, to help the public in reporting complaints and obtaining information on complaint data that has been followed up easily. This research is expected to help the group of health officials in the Bandung Health Office and Technical Implementation Unit in terms of monitoring the public on the side effects and safety of vaccines to know the risks and treatment when unwanted complaints occur. To increase public confidence and acceptance of the COVID-19 vaccination program conducted by the government and health workers to make group immunity (herd immunity). The limitation of this study is the web-based COVID-19 vaccination target complaint monitoring information system used in Bandung City Health Office along with the Health Service Facilities of the Technical Implementation Unit under the auspices of the Health Office. 


\section{METHODOLOGY}

\subsection{Literature Studies}

\subsubsection{Relevant Research}

There are several relevant researches related to the design of compliant information systems, one of which research conducted by Falaah Abdussalaam and Samdea Anggieta Saputra with the title "Design of Information System Complaint Management With RAD Method Using Laravel Framework". This study conducted observations at PT. The mainstay of Mandiri Technology with the availability of problems of unavailable handling of complaints by using information systems that cause subcontractor performance monitoring activities in the field is less effective, the unavailable data history of complaint handling from users. Then it is necessary to build a complaint management Information System with an integrated database so that data management is faster and easy to use [9].

View information from previous research references. This research differs in terms of objects and methods used. Research that makes the design of information systems on complaints using objects related to vaccination has never been done. The system designed is web-based due to compatible access capabilities across all operating systems. Software development methodology using a linear, sequential method of the waterfall. As for analyzing design using an object-oriented modeling approach with UML (Unified Modelling Language). Then the functional system testing stage that will be used is to use the Black box Testing and System Usability Scale as an evaluation of the system. The website programming language used is PHP (Hypertext Preprocessor) using CodeIgniter framework, as well as MySQL as database storage.

\subsubsection{PHP (Hypertext Preprocessor)}

PHP is a server-side programming language. This means that when accessing a URL, the web browser will make a request to a web server [10].

\subsubsection{CodeIgniter}

CodeIgniter is a framework of an open source web application to build dynamic PHP applications and has a library that can make it easier for developers to design applications quickly without writing source code from scratch. CodeIgniter is built with the concept (MVC) Model, View, Controller so that the coding of the program will be more structured and neat [10].

\subsection{Research Methods}

The research methodology that is used in this research is the classic life cycle development model, or also known as the waterfall model. Called like a waterfall because in this case the stages are described with a sequential systematic approach in software development [11]. This stage starts from the activity of analyzing the requirements, then continues through the system design stage, the coding and system implementation stage, and the system unit testing stage (Testing/Verification), as well as system maintenance. By using this method, it is unlikely that an error occurs in the design process, because the stages are carried out in sequence, if one stage has not been completed, it cannot proceed to the next stage so that the processes cannot overlap each other.

In order to obtain information transparently to support the success of research, the way of data collection conducted in this study is by observation, interview, questionnaire, and literature Study. Observations are made by observing and researching the situation in a research subject directly at the Bandung Health Office to find the problem to be raised and obtain transparent

Reihan, et., al [Design of Information System Monitoring Complaints Targeting COVID-19 Vaccination For The General Public Based On The Web (Case Study of Bandung Health Office)] 
data as an analysis and evaluation material on research problems according to the needs. The interview was conducted with a discussion directly to the related party at the Bandung Health Office who will interact directly with the system to obtain the functional needs of the system. Then the collection of data questionnaire is done by making a survey using Google form in the form of questions to the target respondents who have already vaccinated COVID-19, which is necessary for the collection of research data samples that will be used as input data and assessment data in program testing. Literature studies are conducted by collecting references from book sources, news, COVID-19 vaccination documents obtained during vaccination activity, and scientific journals relevant to the topic of research conducted.

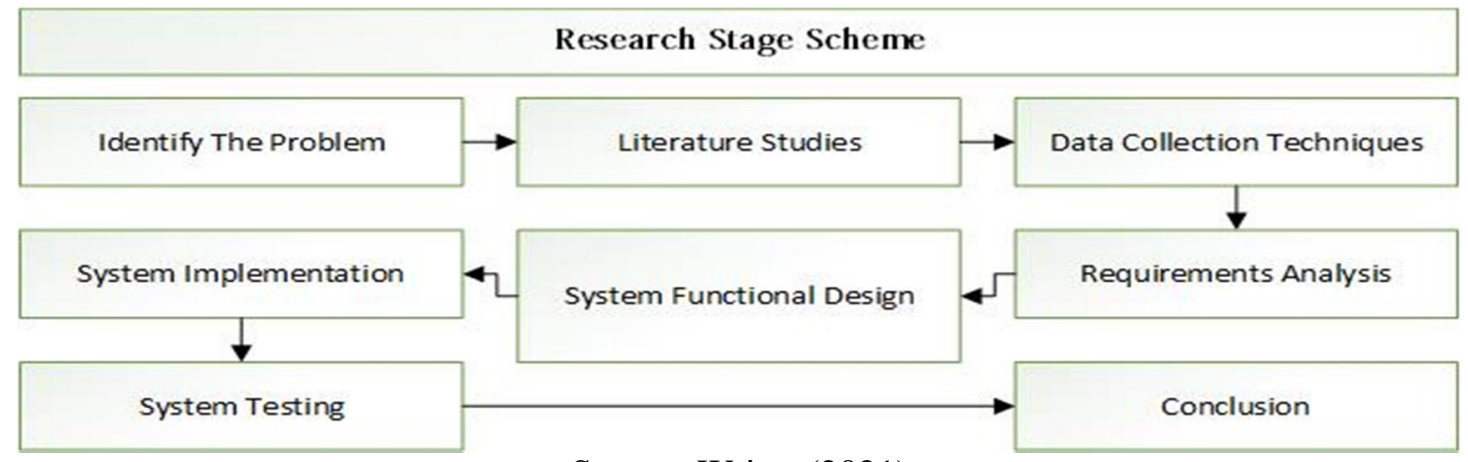

Source: Writer (2021)

Figure 1. Research Method Stage Scheme

Figure 1 is a schematic flow of the stages of research that will be conducted in accordance with the stages of the waterfall research method.

\section{RESULT AND EXPLANATION}

\subsection{Requirements Analysis}

Based on the results of the analysis from the research data that has been collected, the writers obtained the specifications needed by users to use the information system monitoring complaints COVID-19 vaccination based on the web. Two actors can access the system, namely operators, as health workers who handle public complaints, and the whistleblowers as the public who report complaints after COVID-19 vaccination. The defining process between the two actors will be modeled by using the use case diagram that can be seen in (figure 2) to describe the interaction and to know the functions or processes that occur in the system in general.

\subsubsection{User Requirements}

1. Operator Requirements (Health Workers)

The operators can log into the system, manage post-vaccination report data, follow up and respond to reported post-vaccination complaints, view whistleblowers' information data.

2. Whistleblower Requirements (Community)

The whistleblower can report post-vaccination complaints of COVID-19, track or check the status of the results of follow-up complaints that have been reported, view information on post-vaccination complaint data, and information on the results of complaint reporting that has been followed up and responded to. 


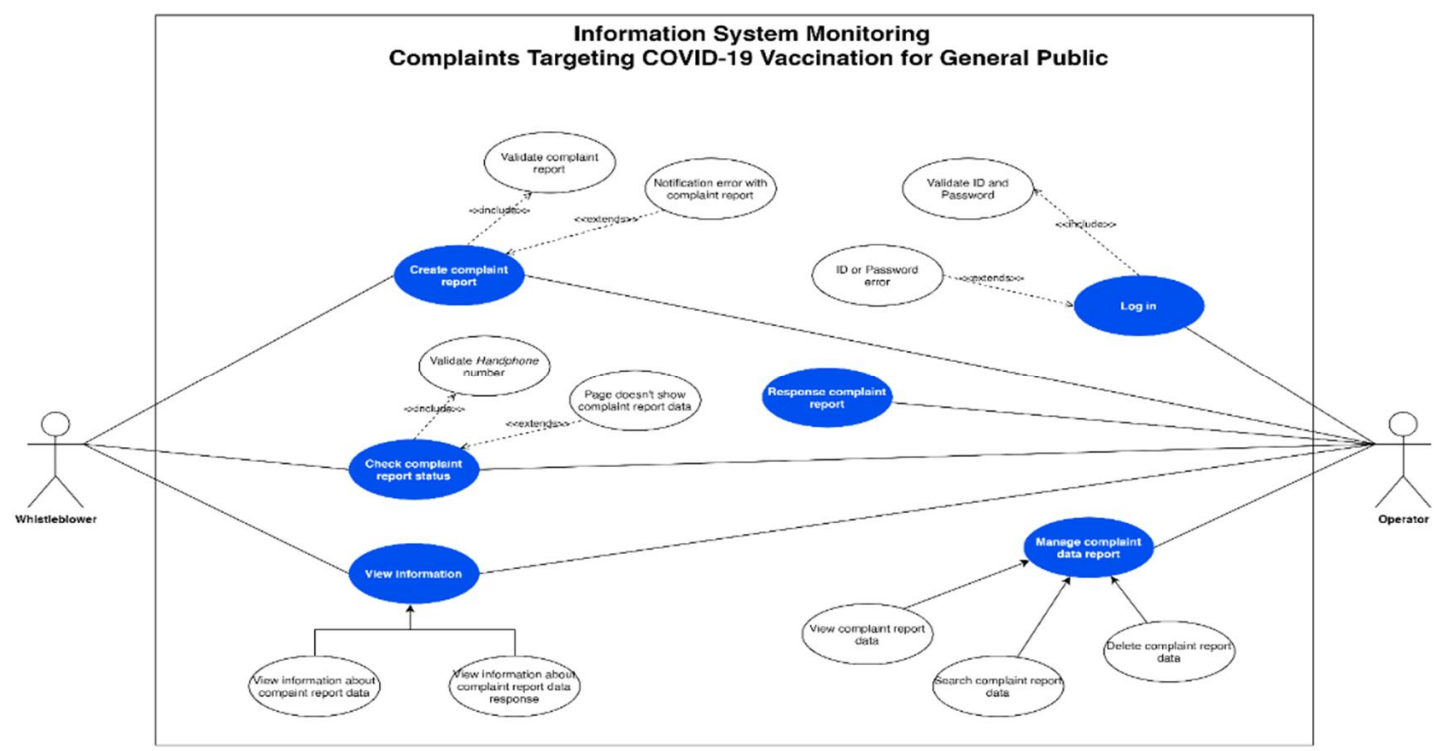

Source: Writer (2021)

Figure 2. Use Case Diagram of The Proposed Covid-19

Vaccination Complaint Monitoring System

Figure 2 shows the interaction process between actors and the system depicted using the Use case diagram, where the actor is the main entity that will use the system. Two actors play a role in carrying out the functions of each use case described in the COVID-19 vaccination target complaint monitoring system. Namely, Whistleblower and Operators, each actor have a different role. In accessing the system, there is no need for the whistleblower to log in first. The Whistleblower can directly create complaint reports, track or check the status of complaint reporting, view complaint reporting data information as well as follow-up information and complaint reporting responses on the main page of the whistleblower. While the Operator must $\log$ in first to access the system in following up, responding, and managing the complaint report data on the operator's main page.

\subsection{System Functional Design}

The functional design of the system is the process of pouring ideas and ideas based on supporting theory and the results of identification of needs that have been analyzed. At this stage, the design will be represented using an object-oriented modeling approach with Unified Modelling Language (UML) in the form of behavioral diagrams.

\subsubsection{Activity Diagram}

An activity diagram is a diagram used to describe the process flow of the system as a whole, as well as only the parts of the system process that you want to describe in detail. Activity diagrams have relationships with external entities and interrelationships between processes that occur within the system [12]. 


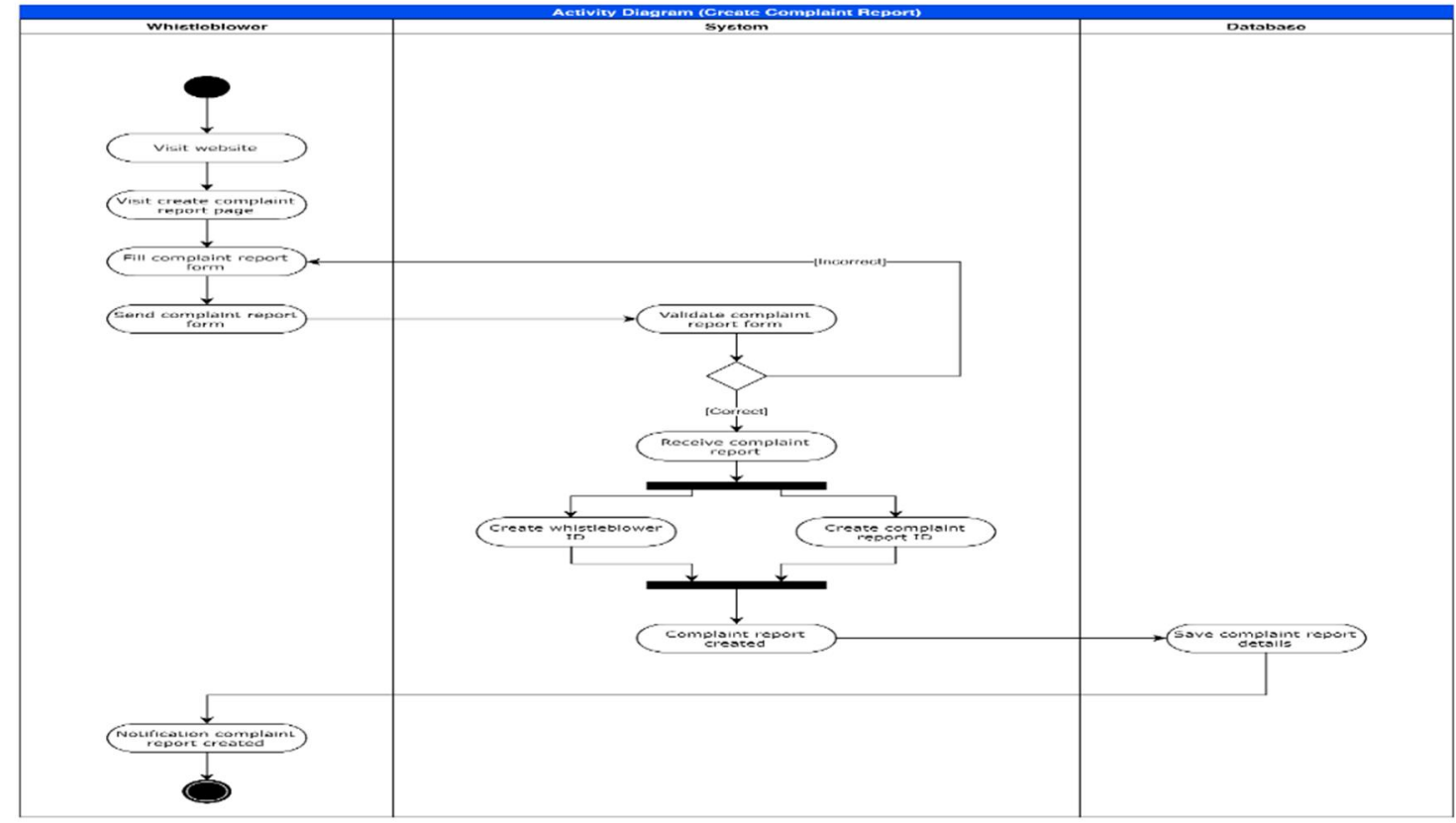

Source: Writer (2021)

Figure 3. Activity Diagram The Whistleblower Makes A COVID-19

Vaccination Complaint Report

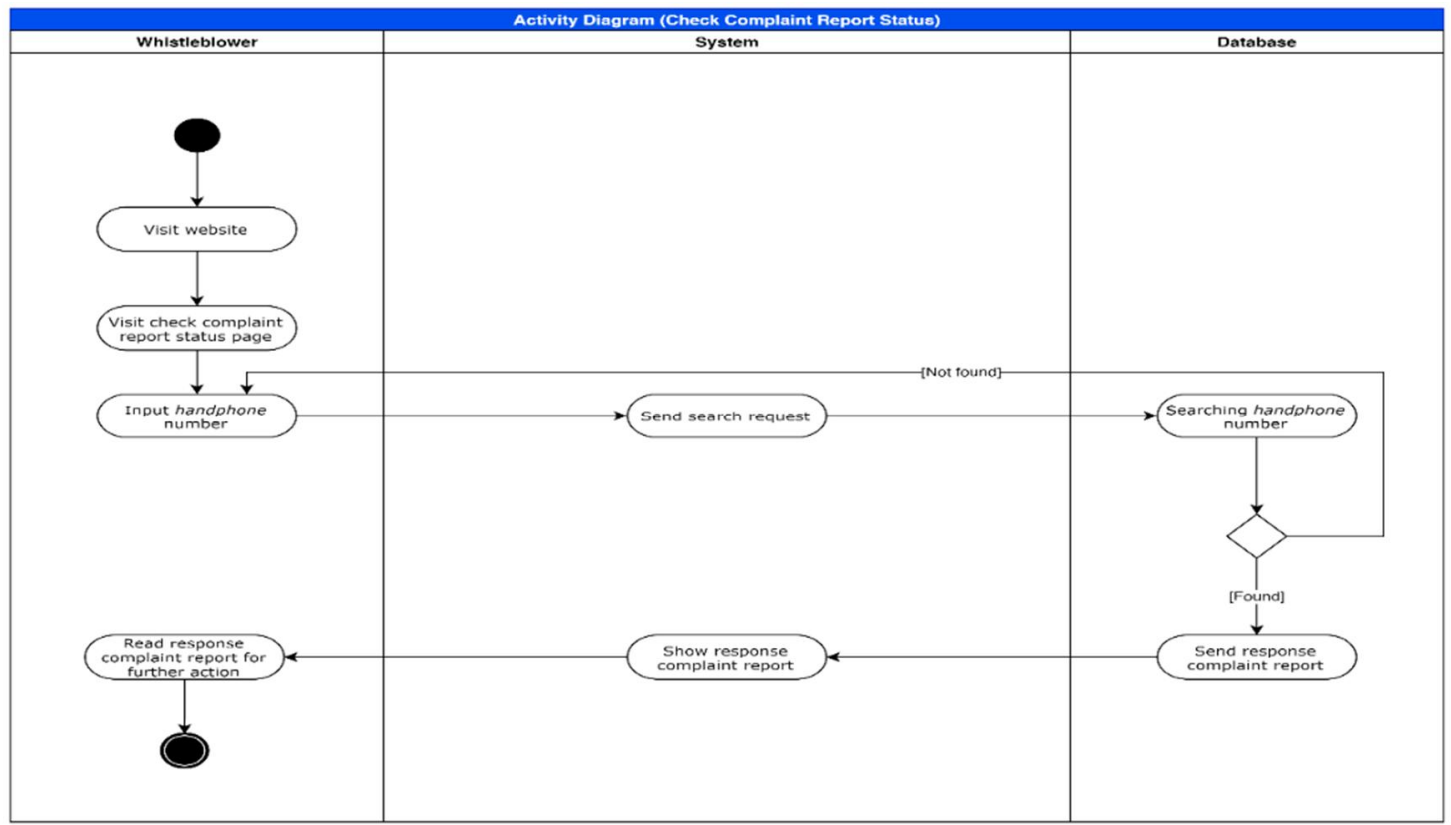

Source: Writer (2021)

Figure 4. Activity Diagram The Whistleblower Tracks and Checks

The Status of Reporting COVID-19 Vaccination Complaints 


\subsubsection{Sequence Diagram}

Sequence diagrams are used to describe the process flow sequentially or linearly by describing messages sent between each object in sequence from the first process to the last process executed. The sequence diagram focuses on process sequences based on units of time [12].

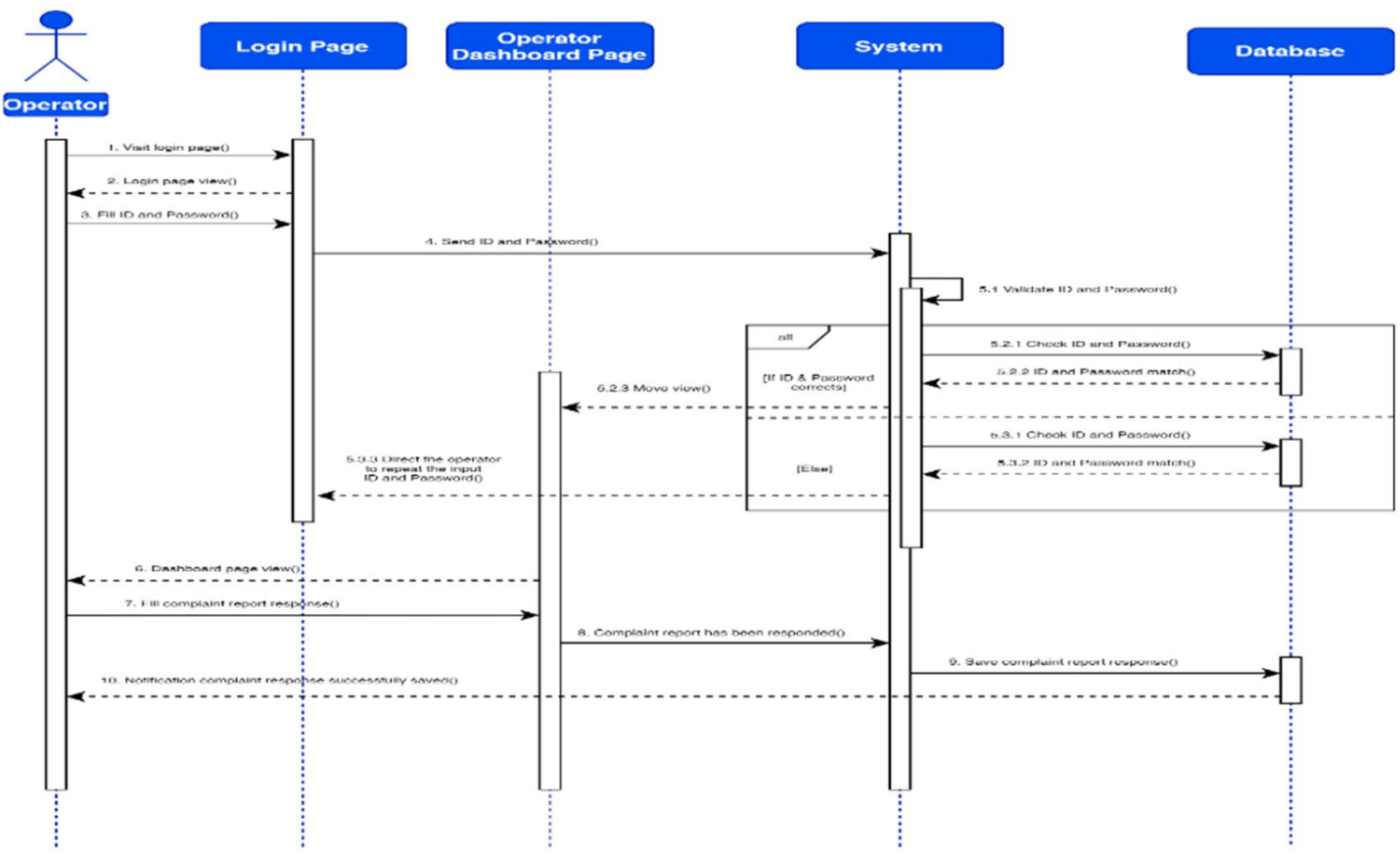

Source: Writer (2021)

Figure 5. Sequence Diagram The Operators Respond to COVID-19 Vaccination Complaints Reporting Data

\subsection{System Implementation}

In the implementation stage of this study has produced a website-based COVID-19 vaccination complaint monitoring information system which can monitor, manage COVID-19 vaccination complaint reporting data well and efficiently, and can respond and follow up on complaints that have been reported by the public quickly and easily. 


\subsubsection{System Interface View}

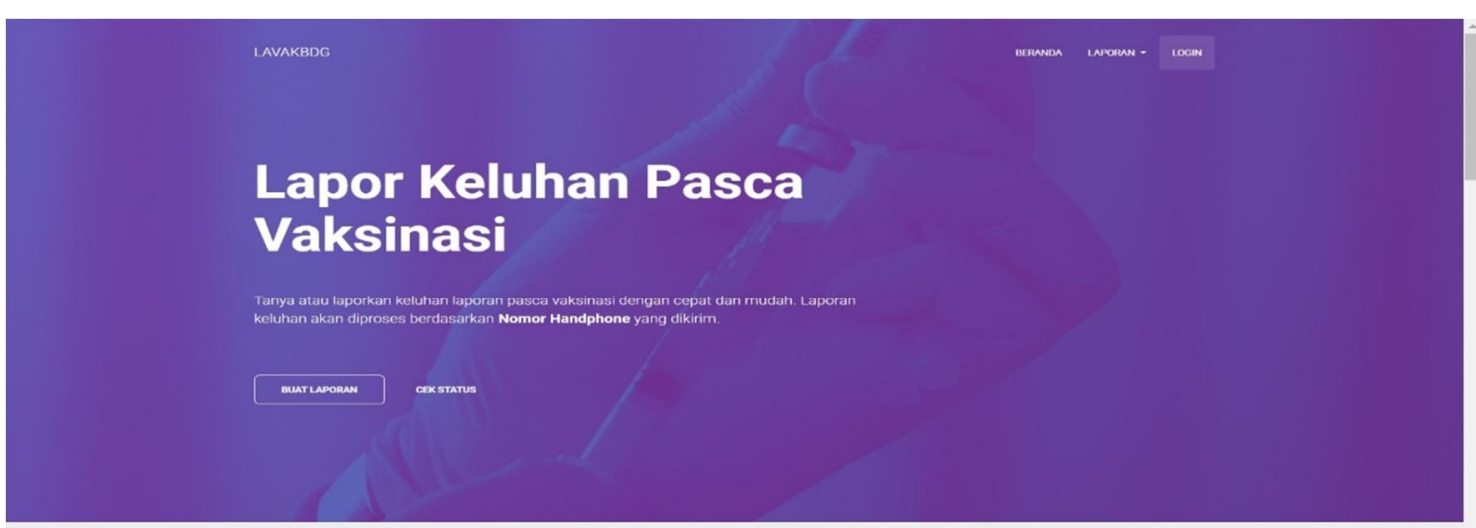

Informasi Lanoran Keluhan

Source: Writer (2021)

Figure 6. View of The Main Page of COVID-19 Post-Vaccination Complaint Reports

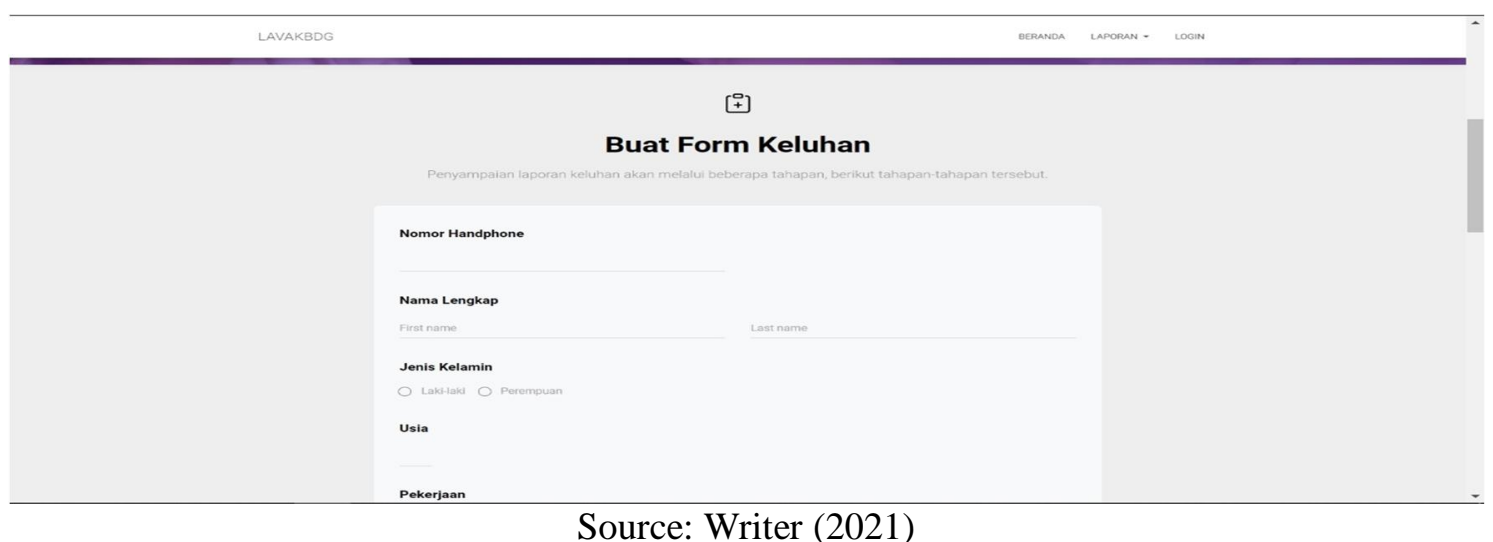

Figure 7. Form View Makes Reporting COVID-19 Vaccination Complaints

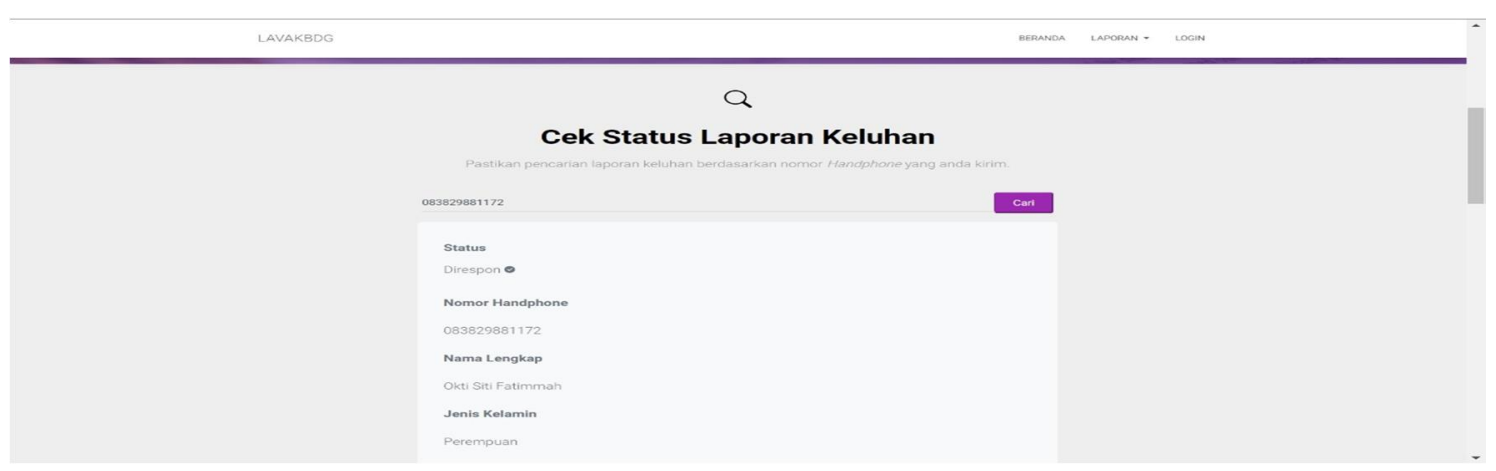




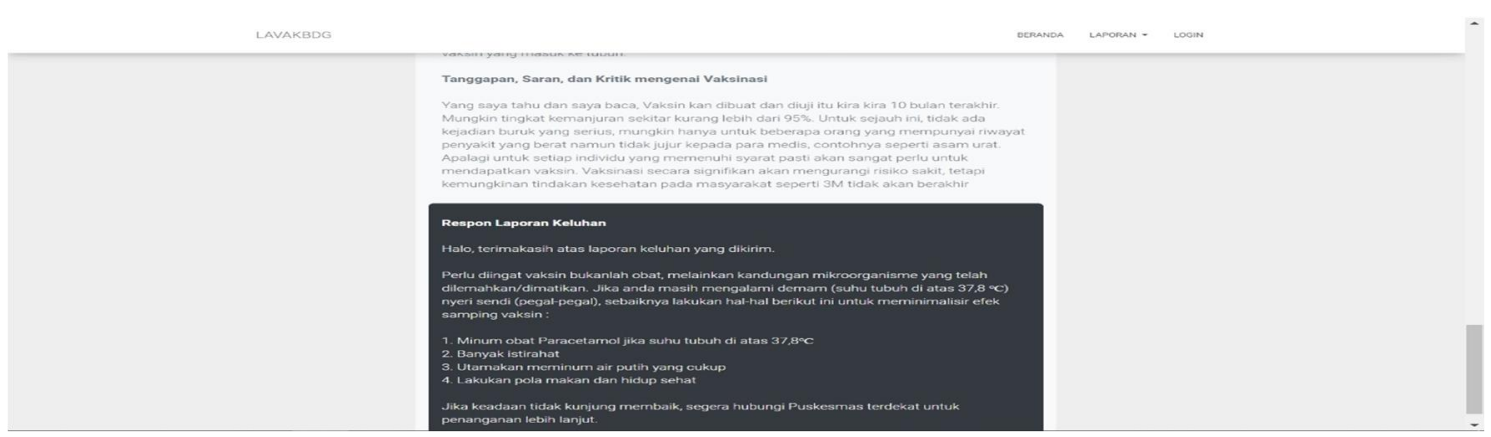

Source: Writer (2021)

Figure 8. COVID-19 Vaccination Complaint Report Status Tracking View
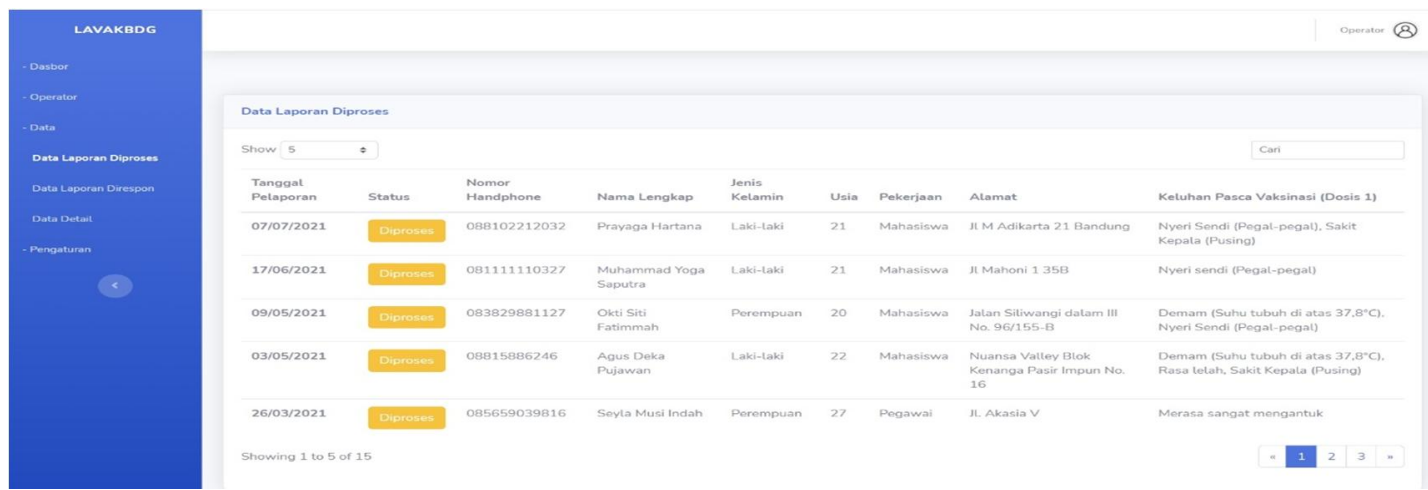

Source: Writer (2021)

Figure 9. Display of Vaccination Complaint Reporting Data On The Operator Page
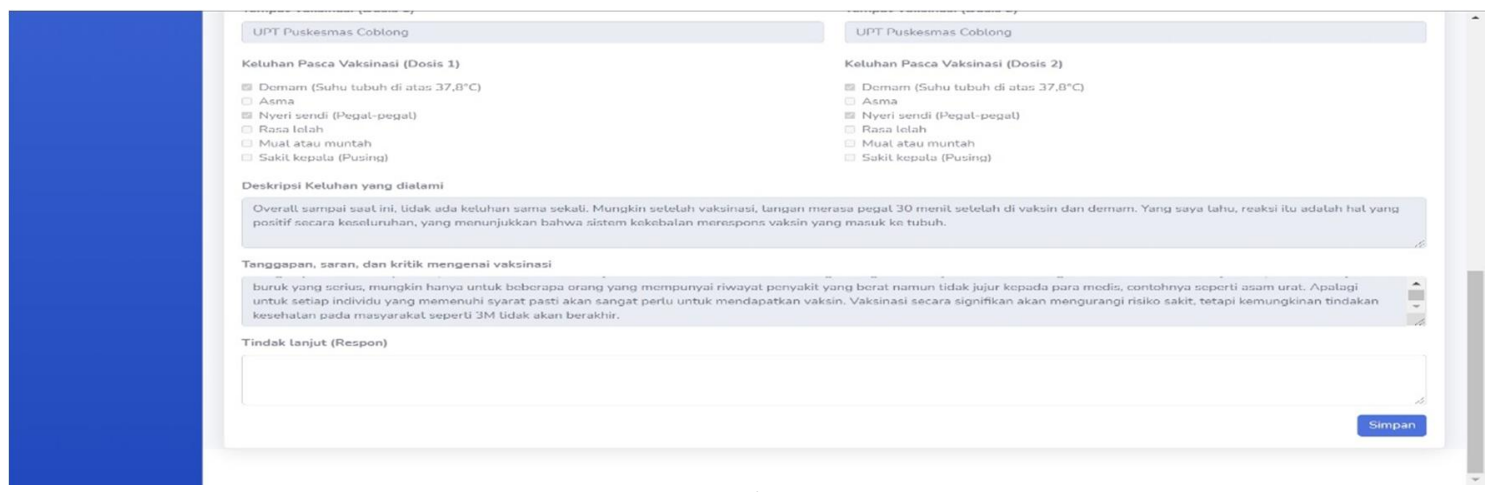

Source: Writer (2021)

Figure 10. View of The Follow-Up Process and Response To Reporting COVID-19 Vaccination Complaints

\subsection{System Testing}

\subsubsection{Black Box Testing}

Black box testing focuses on the system's functional requirements to determine the success rate of a program that aims to find and resolve errors or errors from a set of input conditions in program execution [13]. 
Table 1. Black Box Testing

\begin{tabular}{|c|l|l|l|l|l|}
\hline Num. & $\begin{array}{c}\text { Testing } \\
\text { Functions }\end{array}$ & $\begin{array}{c}\text { Test } \\
\text { Scenarios }\end{array}$ & \multicolumn{1}{|c|}{ Test Case } & \multicolumn{1}{c|}{ Expected results } & Test Results \\
\hline 1 & $\begin{array}{l}\text { Report a } \\
\text { Complaint }\end{array}$ & $\begin{array}{l}\text { The } \\
\text { Whistlebl } \\
\text { ower } \\
\text { Reporting } \\
\text { a } \\
\text { complaint } \\
\text { on the } \\
\text { complaint } \\
\text { s report } \\
\text { page. }\end{array}$ & $\begin{array}{l}\text { The } \\
\text { Whistleblow } \\
\text { er inputs the } \\
\text { data on the } \\
\text { report } \\
\text { complaint } \\
\text { form }\end{array}$ & $\begin{array}{l}\text { If the input data are } \\
\text { complete, then the system } \\
\text { will verify the full data } \\
\text { and save the full data to } \\
\text { the database. If the field is } \\
\text { incorrect or one of the } \\
\text { fields is not filled in, an } \\
\text { "incorrect fill data" or } \\
\text { "please fill in the data } \\
\text { completely" notification } \\
\text { will appear }\end{array}$ & As expected \\
\hline 2 & $\begin{array}{l}\text { Complaint } \\
\text { Response }\end{array}$ & $\begin{array}{l}\text { The } \\
\text { Operators } \\
\text { follow up } \\
\text { on The } \\
\text { Whistlebl } \\
\text { ower } \\
\text { complaint } \\
\text { data }\end{array}$ & $\begin{array}{l}\begin{array}{l}\text { The operator } \\
\text { inputs } \\
\text { complaint } \\
\text { response on } \\
\text { the follow- } \\
\text { up page }\end{array} \\
\text { creates a complaint ID and } \\
\text { saves the complaint } \\
\text { response into the database }\end{array}$ & As expected \\
\hline
\end{tabular}

Test Success Value $=\frac{\text { Total Test Results }}{\text { Total } \text { Overall Tests }} \times 100 \%$

Test Success Value $=\frac{2}{2} \times 100 \%=100 \%$

Black box test success results in a test value of $100 \%$, indicating that the system functionality is running well as per the user's needs without any errors.

\subsubsection{System Usability Scale}

To be able to know the level of acceptance and ease of the Website-Based COVID-19 Vaccination Target Complaint Monitoring System that will be used by users, evaluation testing is conducted with the System Usability Scale (SUS). Usability testing emphasizes respondents on the testing process. This test was conducted by 5 respondents by creating a questionnaire containing 10 questions and 5 choices of answers that will be given, then after the SUS questionnaire data is collected, calculations will be made to obtain the final results of the test scores, by looking at the provisions of SUS assessment based on table 2 [14] against the calculation results that be obtained.

Table 2. Determination of Final Score Assessment (System Usability Scale)

\begin{tabular}{|c|c|c|c|c|}
\hline SUS Score & $\begin{array}{c}\text { Grade } \\
\text { Scale }\end{array}$ & $\begin{array}{c}\text { Adjective } \\
\text { Rating }\end{array}$ & $\begin{array}{c}\text { Percentage } \\
\text { Range Value }\end{array}$ & $\begin{array}{c}\text { Acceptability } \\
\text { Ranges }\end{array}$ \\
\hline$>=80.3$ & A & Excellent & $80 \%-90 \%$ & Acceptable \\
\hline$>=74$ and $<80.3$ & B & Good & $70 \%-80 \%$ & Acceptable \\
\hline$>=68$ and $<74$ & C & Okay & $60 \%-70 \%$ & Marginal (High) \\
\hline$>=51$ and $<68$ & D & Okay & $50 \%-60 \%$ & Marginal (Low) \\
\hline$<51$ & E & Poor & $40 \%-50 \%$ & Not Acceptable \\
\hline
\end{tabular}


Table 3. Answer Options and Likert Scale Scores (System Usability Scale)

\begin{tabular}{|c|c|}
\hline Answer Options & Score \\
\hline Totally Agreed & 5 \\
\hline Agree & 4 \\
\hline Neutral & 3 \\
\hline Disagree & 2 \\
\hline Strongly Disagree & 1 \\
\hline
\end{tabular}

Table 4. Questionnaire Calculation Data Results (System Usability Scale)

\begin{tabular}{|c|c|c|c|c|c|c|c|c|c|c|c|c|c|}
\hline \multirow{2}{*}{$\begin{array}{c}\mathbf{N} \\
\mathbf{u} \\
\mathbf{m}\end{array}$} & $\begin{array}{c}\text { Respon } \\
\text { dents }\end{array}$ & & P1 & P2 & P3 & P4 & P5 & P6 & P7 & P8 & P9 & P10 & Qua \\
ntity & The \\
Value \\
\hline 1 & & & & & & & & & & & & \\
\hline 2 & R1 & 4 & 2 & 4 & 4 & 4 & 2 & 4 & 4 & 3 & 4 & 35 & 88 \\
\hline 3 & R3 & 4 & 4 & 4 & 4 & 2 & 4 & 2 & 4 & 3 & 4 & 35 & 88 \\
\hline 4 & R4 & 3 & 2 & 4 & 4 & 1 & 3 & 4 & 1 & 3 & 1 & 26 & 65 \\
\hline 5 & R5 & 4 & 1 & 3 & 2 & 3 & 4 & 3 & 4 & 2 & 3 & 29 & 73 \\
\hline \multicolumn{10}{|c|}{ Final Result Average SUS Value } \\
\hline
\end{tabular}

Note :
$\mathrm{R} 1-\mathrm{R} 10=$ Respondents
$\mathrm{P} 1-\mathrm{P} 10=$ Question
SUS Value $=$ Number of Question Scores $\times 2.5$
Formula End Result average SUS test value $: \bar{x}=\frac{\sum x}{n}$
$\bar{x}=$ Final Result average SUS test score
$\sum x=$ Total Number of SUS values
$n=$ Number of Respondents

Referring to table 4, the average final result of the System Usability Scale test questionnaire score against the system of 77.6 is in the percentage range of $70 \%-80 \%$, fall into the acceptable acceptance rate category, with grade scale B and adjective rating with good category. The results show respondents accepted that the system could be used easily in the process of reporting complaints and monitoring the status of follow-up and complaint response effectively.

\section{CONCLUSION}

Based on the results of the research stages that have been done, the writers conclude, namely :

1. Website-based COVID-19 Vaccination Target Complaint Monitoring Information System that has been designed can facilitate health officials in the Bandung Health Office and Technical Service Unit under its auspices, in the process of managing COVID-19 vaccination complaint reporting data, so that the recapping complaint report data can be 
stored and monitored properly and can respond and follow-up complaints that have been reported by the public quickly and efficiently.

2 . In the test results, the black box obtained a success percentage value of $100 \%$, indicating the functionality of the system has been running as needed by the user without any problems. Questionnaire results from the System Usability Scale (SUS) evaluation test received an average final result of 77.6 test scores, were in the range of percentage $70 \%-80 \%$, which belonged to the acceptance rate with acceptable category, with grade scale $\mathrm{B}$, and got adjective rating with good category. The results showed that the majority of respondents agreed that the web-based COVID-19 vaccination target complaint monitoring information system, can be used easily by the public in reporting complaints and monitoring the followup status of reported vaccination complaints, so that they can see information about responses to complaint data that have been effectively followed up, by the purpose and expectations of the study.

\section{SUGGESTION}

The suggestions from the writers of the research that has been done as consideration for further system development include :

1. First, the system can be developed in terms of notifications by adding the SMS Gateway feature to provide information on follow-up results and complaint responses that have been reported by the public in real-time.

2. Second, from the platform side can be developed by using an Android-based system that has the need for data access and memory of small devices in order to be practical in accessing the system anywhere and anytime easily using a smartphone.

3. Finally, the system can add interesting and informative features. One of them is information about the number of complaint reports based on the location of the reporter that will be loaded as a map.

\section{GREETINGS THANK YOU}

First of all, the writers thank Allah SWT for the healthy favors and free time during journaling.Then, the writers thank both parents and supervisors who always support the writers in the process of journaling. Not to forget also the writers express thousands of thanks for the support of college friends who struggled together in completing the final task.

Finally, the writers give a special thank you to the reviewer of the JATISI journal who has given the writers the opportunity to try to publish research work.

\section{REFERENCES}

[1] E. Deviona, F. Kanafi, and A. Kusuma, "Sosialisasi Vaksinasi Covid-19," J. Abdimas Bela Negara, Vol. 2, No. April, pp. 80-89, 2021.

[2] "Vaksin Dashboard.” https://vaksin.kemkes.go.id/\#/vaccines (accessed Jul. 11, 2021).

[3] F. Farisa, Chusna, "Jokowi: Tak Ada Tawar-menawar, Juli 1 Juta Vaksin Per Hari, Agustus 2 Juta.” https://nasional.kompas.com/read/2021/06/30/16194681/jokowi-tak-

Reihan, et., al [Design of Information System Monitoring Complaints Targeting COVID-19 Vaccination For The General Public Based On The Web (Case Study of Bandung Health Office)] 
ada-tawar-menawar-juli-1-juta-vaksin-per-hari-agustus-2-juta (accessed Jul. 12, 2021).

[4] I. Akbar, “Vaksinasi Covid-19 dan Kebijakan Negara: Perspektif Ekonomi Politik,” J. Acad. Praja, Vol. 4, No. 1, pp. 244-254, 2021.

[5] N. Lombardi et al., "Vaccines Safety In Children and In General Population: A Pharmacovigilance Study On Adverse Events Following Anti-Infective Vaccination in Italy," Front. Pharmacol., vol. 10, no. AUG, 2019, doi: 10.3389/FPHAR.2019.00948.

[6] H. Lee et al., "Causality Assessment Guidelines For Adverse Events Following Immunization With A Focus On Guillain- Barré Syndrome," Vaccines, Vol. 8, No. 1, Mar. 2020, doi: 10.3390/VACCINES8010101.

[7] C. Alicino et al., "Routine Surveillance of Adverse Events Following Immunization As An Important Tool to Monitor Vaccine Safety,” Hum. Vaccines Immunother., Vol. 11, No. 1, pp. 91-94, Jan. 2015, doi: 10.4161/HV.34360.

[8] I. Ritunga et al., "Penguatan Program Vaksinasi Covid-19 di Wilayah Puskesmas Made Surabaya Barat,” Vol. 5, No. 1, pp. 45-52, 2021.

[9] F. Abdussalaam, S. A. Saputra, P. Studi, M. Informatika, and P. P. Ganesha, “Perancangan Sistem Informasi Complaint Management,” J. E-Komtek, Vol. 2, No. 2, pp. 54-68, 2018.

[10] Y. Purbadian, "Framework Codeigniter 3," p. 144, 2016.

[11] I. Nawawi, “Pemodelan Perangkat Lunak," p. 51, 2017.

[12] G. B. James Rumbaugh, Ivar Jacobson, The Unified Modeling Language Reference Manual. .

[13] A. Rouf, "Pengujian Perangkat Lunak Dengan Menggunakan Metode White Box dan Black Box," pp. 1-7.

[14] U. Ependi, "System Usability Scale Vs Heuristic Evaluation : A Review," Vol. 10, No. 1, pp. 65-74, 2019. 